\title{
High Temperature Dehydroxylation of Apatitic Phosphates
}

\author{
T. Negas and R. S. Roth \\ Institute for Basic Standards, National Bureau of Standards, Washington, D.C. 20234
}

(August 7, 1968)

\begin{abstract}
$\mathrm{Sr}_{10} \mathrm{P}_{6} \mathrm{O}_{24}(\mathrm{OH})_{2}$, (Hex. $a=9.765 \AA, c=7.280 \AA$ ), and $\mathrm{Ba}_{10} \mathrm{P}_{6} \mathrm{O}_{24}(\mathrm{OH})_{2}$, (Hex. $a=10.177 \AA, c=7.731$ $\AA$ ), undergo cell parameter contractions at elevated temperatures in air. These can be correlated with progressive dehydroxylation, although neither can be completely dehydrated. $\mathrm{Pb}_{10} \mathrm{P}_{6} \mathrm{O}_{24}(\mathrm{OH})_{2}$, $(\mathrm{Hex}$. $a=9.878 \AA, c=7.432 \AA$ ), also does not completely dehydrate in air.

A new apatite-like strontium phosphate, (Hex. $a=9.872 \AA, c=7.199 \AA$ ), was prepared at elevated temperatures in vacuum.

Key Words: Apatite, dehydroxylation, high temperature, phosphates, x-ray diffraction.
\end{abstract}

\section{Introduction}

The existence of the so-called oxyapatites, has been a subject of much controversy. Associated is the problem concerning the existence and nature of phases produced from the dehydroxylation of hydroxyapatite. The general cell content formula for hydroxyapatite is

$$
\mathrm{A}_{10} \mathrm{~B}_{6} \mathrm{O}_{24}(\mathrm{OH})_{2} \text {, space group } \mathrm{P}_{3} / \mathrm{m}
$$

where $\mathrm{A}$ is a large cation distributed in 7- and 9-fold sites $[1]^{1}$ and $\mathrm{B}$ a small cation in tetrahedral coordination. Ideally, each $(\mathrm{OH})^{-}$is shared by three $\mathrm{A}$ ions. Dehydroxylation or substitution by $\mathrm{O}^{-2}$ for $(\mathrm{OH})^{-}$ may result in the formation of true oxyapatites in a number of ways.

If two $\mathrm{O}^{-2}$ anions replace the two $(\mathrm{OH})^{-}$groups excess negative charge results. This necessitates either a valence change in the $\mathrm{A}$ or $\mathrm{B}$ cation sites or a change in the ratio of the constituents with the appearance of additional phases. Such compounds as $\mathrm{Sr}_{10} \mathrm{Cr}_{6}^{5+} \mathrm{O}_{24}(\mathrm{OH})_{2}$ and $\mathrm{Ba}_{10} \mathrm{Cr}_{6}^{5+} \mathrm{O}_{24}(\mathrm{OH})_{2}$ have oxyapatite counterparts which appear to be $\mathrm{Sr}_{10} \mathrm{Cr}_{4}^{5+} \mathrm{Cr}_{2}^{6+} \mathrm{O}_{24} \mathrm{O}_{2}$ and $\mathrm{Ba}_{10} \mathrm{Cr}_{4}^{5+} \mathrm{Cr}_{2}^{6+} \mathrm{O}_{24} \mathrm{O}_{2}$ [2]. The hydroxyapatites $\mathrm{Sr}_{4} \mathrm{La}_{6} \mathrm{Si}_{6} \mathrm{O}_{24}(\mathrm{OH})_{2}$ and $\mathrm{Na}_{2} \mathrm{La}_{8} \mathrm{Si}_{6} \mathrm{O}_{24}(\mathrm{OH})_{2}$ dehydrate to oxyapatites according to:

$$
\begin{aligned}
8 \mathrm{Sr}_{4} \mathrm{La}_{6} \mathrm{Si}_{6} \mathrm{O}_{24}(\mathrm{OH})_{2} \stackrel{1100}{ } \stackrel{{ }^{\circ} \mathrm{C}}{\rightarrow} 6 \mathrm{Sr}_{2} \mathrm{La}_{8} \mathrm{Si}_{6} \mathrm{O}_{24} \mathrm{O}_{2} \\
\\
+10 \mathrm{Sr}_{2} \mathrm{SiO}_{4}+2 \mathrm{SiO}_{2}+8 \mathrm{H}_{2} \mathrm{O}(\mathrm{g})
\end{aligned}
$$

and

$$
9 \mathrm{Na}_{2} \mathrm{La}_{8} \mathrm{Si}_{6} \mathrm{O}_{24}(\mathrm{OH})_{2} \stackrel{1100}{\rightarrow} \mathrm{C} 8 \mathrm{NaLa}_{9} \mathrm{Si}_{6} \mathrm{O}_{24} \mathrm{O}_{2}
$$

\footnotetext{
${ }^{1}$ Figures in brackets indicate the literature references at the end of this paper.
}

$$
+\left(5 \mathrm{Na}_{2} \mathrm{O}: 6 \mathrm{SiO}_{2}\right)_{\mathrm{glass}}+9 \mathrm{H}_{2} \mathrm{O}(\mathrm{g})
$$

respectively [3]. Unit cell dimensions of all of the above oxyapatites are substantially different from those of their correspondingly related hydroxyapatites.

Theoretically, when the aforementioned mechanisms cannot operate, charge neutrality can be accomplished by the substitution of only one $\mathrm{O}^{-2}$ for two $(\mathrm{OH})^{-}$. Such a mechanism creates vacancies in half the available positions, an unacceptable condition to some workers [4, 5]. Nevertheless, such compounds as $\mathrm{Ba}_{10} \mathrm{P}_{6} \mathrm{O}_{24}\left(\mathrm{OH}_{2}\right), \mathrm{Pb}_{10} \mathrm{P}_{6} \mathrm{O}_{24}(\mathrm{OH})_{2}$, and $\mathrm{Sr}_{10} \mathrm{P}_{6} \mathrm{O}_{24}(\mathrm{OH})_{2}$ have teen reported to have $\mathrm{A}_{10} \mathrm{~B}_{6} \mathrm{O}_{24} \mathrm{O}$ type oxyanalogs $[6,7,8]$. This paper deals with this class of hydroxyapatites and the question concerning the existence of oxy-analogs.

Recently, Kreidler and Hummel [8] reported that they synthesized $\mathrm{Sr}_{10} \mathrm{P}_{6} \mathrm{O}_{24} \mathrm{O}$ by the debydroxylation of $\mathrm{Sr}_{10} \mathrm{P}_{6} \mathrm{O}_{24}(\mathrm{OH})_{2}$ above $1400{ }^{\circ} \mathrm{C}$ in air and at $1400{ }^{\circ} \mathrm{C}$ in vacuum. From phase equilibria considerations they reasoned that a series of solid solutions exists between the hydroxy and oxyapatite having the general formula

$$
\mathrm{Sr}_{10} \mathrm{P}_{6} \mathrm{O}_{24}(\mathrm{OH})_{2-2 \mathrm{x}} \mathrm{O}_{\mathrm{x}} \mathrm{V}_{\mathrm{x}}
$$

where $\mathrm{O} \leqq \mathrm{X} \leqq 1$ and $\mathrm{V}=\mathrm{a}$ vacancy. Furthermore, x-ray powder patterns of $\mathrm{Sr}_{10} \mathrm{P}_{6} \mathrm{O}_{24}(\mathrm{OH})_{2}$, synthesized below $1400{ }^{\circ} \mathrm{C}$, and $\mathrm{Sr}_{10} \mathrm{P}_{6} \mathrm{O}_{24} \mathrm{O}$ were said to be identical. This latter interpretation seemed untenable considering the gross "defectiveness" of the oxyapatite phase. The writers have reinvestigated in detail the behavior of $\mathrm{Sr}_{10} \mathrm{P}_{6} \mathrm{O}_{24}(\mathrm{OH})_{2}$ at elevated temperatures and extended the interpretation of these results to data obtained for barium-phosphorus and leadphosphorus analogs. 


\section{Experimental Procedure}

Starting materials of $\mathrm{Sr}_{10} \mathrm{P}_{6} \mathrm{O}_{24}(\mathrm{OH})_{2}$ and $\mathrm{Ba}_{10} \mathrm{P}_{6} \mathrm{O}_{24^{-}}$ $(\mathrm{OH})_{2}$ were prepared in air by heating pressed pellets of the appropriate carbonate and $\mathrm{NH}_{4} \mathrm{H}_{2} \mathrm{PO}_{4} \quad(10: 6$ molar ratio mixture) from room temperature to $300{ }^{\circ} \mathrm{C}$, then at $600{ }^{\circ} \mathrm{C}$ and $900{ }^{\circ} \mathrm{C}$ with intermediąte grinding and pressing. ${ }^{2}$ To avoid reaction of the alkaline earths, particularly barium, with platinum, syntheses were carried out on gold. The $900{ }^{\circ} \mathrm{C}$ Sr-apatite starting material was not effervesecent in HCl. The $900{ }^{\circ} \mathrm{C}$ Ba-apatite, however, was weakly effervescent indicating either retention of carbonate as a structural component or free unreacted $\mathrm{BaCO}_{3}$. Specimens heated above $1000{ }^{\circ} \mathrm{C}$ were not effervescent in $\mathrm{HCl}$. Portions of each apatite batch were mixed with distilled water, sealed in platinum capsules and reheated at $300{ }^{\circ} \mathrm{C}$ for five days in a Morey bomb. X-ray powder patterns of the phases produced in such a hydrothermal manner are identical to those synthesized in air. The strontium apatite was heated at $100{ }^{\circ} \mathrm{C}$ intervals in open gold envelopes (below $1000{ }^{\circ} \mathrm{C}$ ) or platinum tubes $\left(>1000{ }^{\circ} \mathrm{C}\right)$, using small portions of the apatite previously synthesized in air. Above $1100{ }^{\circ} \mathrm{C}$, the barium apatite could not be investigated using platinum tubes because of reaction with the metal. Instead, thin pressed wafers of the starting material were placed on two strands of fine platinum wire wrapped around an alumina dish and heated in this suspended manner.

Lead-phosphorous apatite was prepared in air and hydrothermally by the procedures described above except that the monoxide was used as the large cation source.

Specimens were heated in a platinum-wound tubetype horizontal furnace and cooled by rapid withdrawal. A number of heat treatments were made in vacuum using a modified quench furnace.

Phase analysis was accomplished predominantly by x-ray powder diffraction at room temperature using Ni-filtered copper radiation and $\frac{1}{4} \operatorname{deg} 2 \theta$ per minute diffractometer scanning rate. Parameters may be considered to be accurate to \pm 2 in the last decimal place listed. Supporting data were obtained by gravimetric measurements and nuclear magnetic resonance. Specimens for NMR examination were immediately transferred from the furnace to evacuated vycor tubes and sealed against contamination from atmospheric moisture.

\section{Results and Discussion}

\section{1. $\mathrm{Sr}_{10} \mathrm{P}_{6} \mathrm{O}_{24}(\mathrm{OH})_{2}$}

The $\mathrm{x}$-ray powder patterns of hydrothermal and low temperature $\left(<900{ }^{\circ} \mathrm{C}\right)$ "in air" apatite are identical and can be completely indexed on the basis of an hexagonal cell having $a=9.765 \AA$ and $c=7.280 \AA$.

${ }^{2}$ Infrared absorption analysis indicated the presence of about 0.2 percent and 0.5 percen carbonate in the starting Sr-and Ba-apatites, respectively. Personal communication, Dr. Bruce Fowler, National Institutes of Health.
On this basis, the $900{ }^{\circ} \mathrm{C}$ phase was considered fully hydroxylated and used as a compositional reference point for further experiments. With increasing temperature, commencing near $1000{ }^{\circ} \mathrm{C}$, (fig. 1), unit-cell parameters continuously contract, reaching values of $a=9.724 \AA$ and $c=7.263 \AA$ at $1600{ }^{\circ} \mathrm{C}$. Pertinent experimental data are given in table 1 . The compound does not decompose with complete loss of $\mathrm{H}_{2} \mathrm{O}$ at a fixed temperature as does, for example, $\mathrm{Sr}_{10} \mathrm{Cr}_{6} \mathrm{O}_{24}(\mathrm{OH})_{2}[2]$.

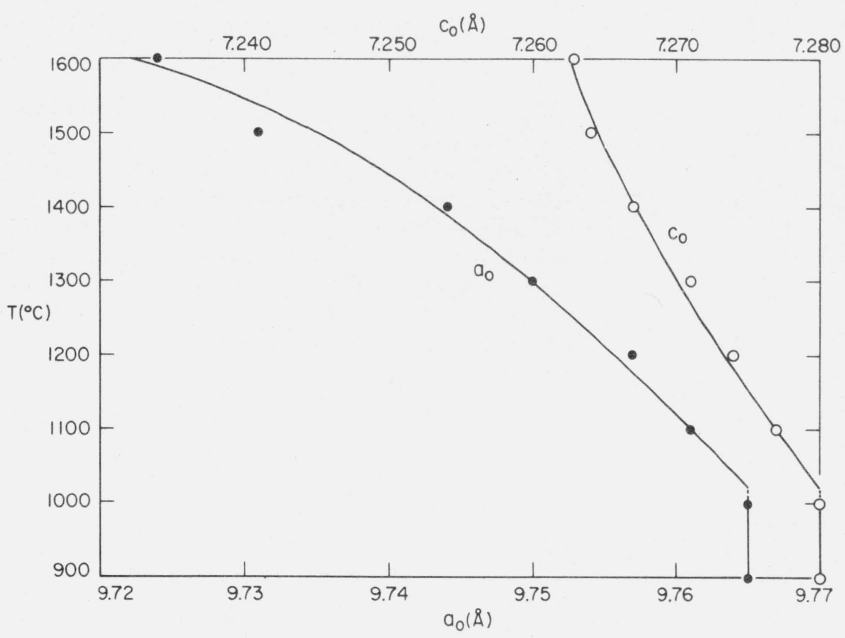

FIGURE 1. Unit-cell parameter changes of strontium-phosphorus apatite as a function of the temperature of heating in air.

Kreidler and Hummel [8] apparently failed to observe this unit cell contraction ${ }^{3}$ but on reasonable thermodynamic grounds concluded that $\mathrm{Sr}_{10} \mathrm{P}_{6} \mathrm{O}_{24}(\mathrm{OH})_{2}$ dehydroxylates in air with increasing temperature until above $1400{ }^{\circ} \mathrm{C} \mathrm{Sr}_{10} \mathrm{P}_{6} \mathrm{O}_{24} \mathrm{O}$ exists. As shown in figure 1 , cell contraction continues beyond $1400{ }^{\circ} \mathrm{C}$ and parameters do not attain constant values as would be expected if total dehydroxylation to $\mathrm{Sr}_{10} \mathrm{P}_{6} \mathrm{O}_{24} \mathrm{O}$ occurs. This suggests that even above $1400{ }^{\circ} \mathrm{C}$ a partially hydroxylated phase exists. A specimen of $\mathrm{Sr}_{10} \mathrm{P}_{6} \mathrm{O}_{24}(\mathrm{OH})_{2}$, heated $40 \mathrm{hr}$ at $1500{ }^{\circ} \mathrm{C}$ lost weight and then after reheating for $50 \mathrm{hr}$ on gold at $900{ }^{\circ} \mathrm{C}$ regained weight suggesting the composition of the phase at $1500{ }^{\circ} \mathrm{C}$ to be

$$
\mathrm{Sr}_{10} \mathrm{P}_{6} \mathrm{O}_{24}(\mathrm{OH})_{0.74} \mathrm{O}_{0.63} \mathrm{~V}_{0.63}
$$

after compensation for loss of $\mathrm{P}_{2} \mathrm{O}_{5}$ at the higher temperature. Furthermore, NMR data unequivocably established the presence of protons in a specimen heated only at $1500{ }^{\circ} \mathrm{C}$. ${ }^{3}$ After the completion of this manuscript, the writers received data from the dissertation
of Kreidler (Ph.D. Thesis, The Pennsylvania State University, 1967). Cell contraction was observed with a conversion of hydroxy- to oxy-apatite in air at $1510 \pm 15^{\circ} \mathrm{C}$. 
TABLE 1. Experimental Data for the Dehydroxylation of Phosphates

Strontium-Phosphorus Apatite *

\begin{tabular}{|c|c|c|c|c|}
\hline$T\left({ }^{\circ} \mathrm{C}\right)$ & Time (hrs) & $a(\AA)$ & $c(\AA)$ & Comments \\
\hline 800 & 100 & 9.765 & 7.280 & \\
\hline 900 & 100 & 9.765 & 7.280 & $\mathrm{NMR}^{* *}$ \\
\hline 300 & 120 & 9.765 & 7.280 & Hydrothermally prepared. \\
\hline 1000 & 70 & 9.765 & 7.280 & \\
\hline 1100 & 70 & 9.761 & 7.277 & \\
\hline 1200 & 40 & 9.757 & 7.274 & \\
\hline 1300 & 70 & 9.750 & 7.271 & \\
\hline 1400 & 30 & 9.744 & 7.267 & \\
\hline 1500 & $2,20,40$ & 9.731 & 7.264 & NMR ** \\
\hline 1600 & 1 & 9.724 & 7.263 & \\
\hline 900 & 5 & 9.765 & 7.280 & Reversed from $1500^{\circ} \mathrm{C}$ \\
\hline 900 & 50 & 9.765 & 7.280 & $\begin{array}{l}\text { Reversed from } 1500{ }^{\circ} \mathrm{C} ; \\
\mathrm{Sr}_{10} \mathrm{P}_{6} \mathrm{O}_{24}(\mathrm{OH})_{0.74} \mathrm{O}_{0.63} \mathrm{~V}_{0.63} \\
\text { from weight loss and regain. }\end{array}$ \\
\hline 900 & 17 & 9.765 & 7.280 & Reversed from $1400^{\circ} \mathrm{C}$. \\
\hline 1400 & 68 & 9.744 & 7.267 & Reheat of $1500^{\circ} \mathrm{C}$ specimen. \\
\hline 1500 & 2 & 9.731 & 7.264 & $\begin{array}{l}\text { Reheat of hydrothermal } \\
\text { specimen. }\end{array}$ \\
\hline 1500 & 4 & 9.731 & 7.264 & $\begin{array}{l}\text { Initially a } 3: 1 \text { mixture of } \mathrm{Sr}_{3}\left(\mathrm{PO}_{4}\right)_{2} \\
\text { and } \mathrm{SrCO}_{3} \text {. }\end{array}$ \\
\hline 1100 & 70 & $\begin{array}{l}9.84 \\
9.72\end{array}$ & $\begin{array}{l}7.21 \\
7.26\end{array}$ & Vacuum, $10^{-2}$ torr; two phases. \\
\hline 1250 & 113 & 9.729 & 7.240 & Vacuum, $2 \times 10^{-2}$ torr. \\
\hline 1270 & 70 & 9.872 & 7.199 & Vacuum, $7 \times 10^{-3}$ torr. \\
\hline 1275 & 110 & 9.872 & 7.199 & Vacuum, $10^{-2}$ torr. \\
\hline 1350 & 115 & 9.728 & 7.240 & Vacuum, $2 \times 10^{-2}$ torr; NMR.** \\
\hline 1500 & 15 & 9.726 & 7.246 & $\begin{array}{l}\text { Vacuum; } 3.8 \times 10^{-4} \text { torr. } \mathrm{Sr}_{4} \mathrm{P}_{2} \mathrm{O}_{9} \\
\text { present; NMR analysis. }\end{array}$ \\
\hline 950 & 310 & 9.827 & 7.234 & $\begin{array}{l}\text { Reheat of } 1270{ }^{\circ} \mathrm{C}, 7 \times 10^{-3} \text { torr } \\
\text { material in air. }\end{array}$ \\
\hline
\end{tabular}

Barium-Phosphorus Apatite*

\begin{tabular}{r|r|l|l|l}
\hline 700 & 96 & 10.177 & 7.731 & \\
900 & 120 & 10.177 & 7.731 & NMR.** \\
300 & 120 & 10.177 & 7.731 & Hydrothermally prepared. \\
1000 & 50 & 10.175 & 7.728 & \\
1200 & 20 & 10.170 & 7.719 & \\
1300 & 20 & 10.164 & 7.714 & \\
1400 & 48 & 10.157 & 7.705 & \\
1500 & 20 & 10.148 & 7.696 & \\
1500 & 20 & 10.148 & 7.696 & NMR.** \\
1600 & 2 & 10.153 & 7.696 & Partly melted? \\
900 & 5 & 10.177 & 7.731 & Reheat of $1500^{\circ} \mathrm{C}$ specimen. \\
900 & 16 & 10.177 & 7.731 & Reheat of $1400^{\circ} \mathrm{C}$ specimen. \\
\hline
\end{tabular}

Lead-Phosphorus Apatite*

\begin{tabular}{|c|c|c|c|c|}
\hline 300 & 120 & 9.878 & 7.432 & Hydrothermally prepared. \\
\hline 700 & 65 & 9.825 & 7.421 & $\begin{array}{l}\text { Reheat of hydrothermal specimen; } \\
\mathrm{Pb}_{10} \mathrm{P}_{6} \mathrm{O}_{24}(\mathrm{OH})_{0.26} \mathrm{O}_{0.87} \mathrm{~V}_{0.87} \\
\text { by weight loss. }\end{array}$ \\
\hline 900 & 50 & 9.825 & 7.421 & \\
\hline 925 & 75 & 9.825 & 7.421 & $\begin{array}{l}\text { Reheat of } 700{ }^{\circ} \mathrm{C} \text { specimen; } \\
\text { NMR.** }\end{array}$ \\
\hline 1000 & & 9.825 & 7.421 & $\begin{array}{l}\text { Melted and slow cooled to } 950^{\circ} \mathrm{C} \\
\text { in } \frac{1}{2} \mathrm{hr} \text {. }\end{array}$ \\
\hline
\end{tabular}

*Unless otherwise indicated, heat treatments were made in air using starting material synthesized in air at $900{ }^{\circ} \mathrm{C}$.

**NMR analysis indicated the presence of protons.

A number of questions naturally arise at this point. Do the curves shown in figure 1 represent equilibrium conditions, i.e., for each temperature at a fixed partial pressure of $\mathrm{H}_{2} \mathrm{O}$ does there exist a stable anion deficient apatite characterized by specific unit cell parameters, or can the data be equally interpreted as being the manifestation of a kinetic problem in which $\mathrm{Sr}_{10} \mathrm{P}_{6} \mathrm{O}_{24}(\mathrm{OH})_{2}$ converts very sluggishly, yet with increasing rate with increased temperature, to $\mathrm{Sr}_{10} \mathrm{P}_{6} \mathrm{O}_{24} \mathrm{O}$ through a series of defect states? If at each temperature there does exist an equilibrium phase characterized by a specific ratio of $(\mathrm{OH})^{-}: \mathrm{O}^{-2}$ : vacancies with unique cell parameters, a thermody- namically possible situation, are the anions and vacancies statistically disordered resulting in a true nonstoichiometric solid solution?

Specimens, generally, were heated for periods up to $100 \mathrm{hr}$ to insure sufficient time to attain reproducible results. For example, specimens held $2 \mathrm{hr}, 20 \mathrm{hr}$, and $40 \mathrm{hr}$ at $1500{ }^{\circ} \mathrm{C}$ yielded apatite phases with identical cell parameters. The $20 \mathrm{hr} 1500^{\circ} \mathrm{C}$ specimen, held $68 \mathrm{hr}$ at $1400{ }^{\circ} \mathrm{C}$, and the $100 \mathrm{hr} 900{ }^{\circ} \mathrm{C}$ specimen, held directly at $1400{ }^{\circ} \mathrm{C}$ for $30 \mathrm{hr}$, yielded identical cell parameters. A 3:1 molar mixture of $\mathrm{Sr}_{3}\left(\mathrm{PO}_{4}\right)_{2}$ and $\mathrm{SrCO}_{3}$ was heated directly at $1500{ }^{\circ} \mathrm{C}$ for $4 \mathrm{hr}$ and, although it did not react completely to a single phase within this time, the predominant phase was apatite with cell dimensions identical to those previously observed at $1500{ }^{\circ} \mathrm{C}$. High temperature phases are readily reversed by reheating at lower temperatures, as shown in table 1 .

The reversibility of the process shows that a kinetic problem is not involved, however, the nature of the anion vacancy is not revealed. Thus, the best interpretation of the behavior of $\mathrm{Sr}_{10} \mathrm{P}_{6} \mathrm{O}_{24}(\mathrm{OH})_{2}$ at elevated temperatures is that increasing dehydroxylation occurs with increasing temperature and is associated with unit cell contraction. Regardless of the true nature of the high temperature phase, a completely dehydroxylated $\mathrm{Sr}_{10} \mathrm{P}_{6} \mathrm{O}_{24} \mathrm{O}$ definitely was not found in air.

A number of experiments, made in vacuum, also provide some interesting observations concerning the dehydroxylation of $\mathrm{Sr}_{10} \mathrm{P}_{6} \mathrm{O}_{24}(\mathrm{OH})_{2}$. A specimen heated $70 \mathrm{hr}$ at $1100{ }^{\circ} \mathrm{C}$ and $10^{-2}$ torr clearly showed two phases, one having cell dimensions quite similar to the $1600{ }^{\circ} \mathrm{C}$ in air phase, the other $a=9.84 \AA$ and $c=7.21 \AA$. The diffuseness of the powder pattern precluded a more precise calculation of cell parameters. Another specimen held $110 \mathrm{hr}$ at $1275^{\circ} \mathrm{C}$ and $10^{-2}$ torr consisted of an apatite-like single phase whose pattern could be completely indexed on the basis of a hexagonal cell with $a=9.872 \AA$ and $c=7.199 \AA$. The compound was again prepared at $1270^{\circ} \mathrm{C}, 70 \mathrm{hr}$ and $7 \times 10^{-3}$ torr. Portions of the powder pattern of this new phase are compared to those of the $900{ }^{\circ} \mathrm{C}$ and $1500{ }^{\circ} \mathrm{C}$ in air apatite phases in figure 2 .

Considering the trend established in the "in-air" experiments, that the cell contracts with hydroxyl loss, this new phase is unusual because of its rather large $a$ and quite small $c$. When heated in air at $950^{\circ} \mathrm{C}$, the compound apparently reacts with atmospheric moisture very sluggishly and $a$ contracts and $c$ expands toward the values of the fully hydroxylated apatite. Unfortunately, the nature of this new phase could not be investigated in detail because of difficulty in the preparation of sufficiently large quantities of material for gravimetric experiments and NMR analysis. ${ }^{4}$ Whether or not it represents a true, ordered, $\mathrm{Sr}_{10} \mathrm{P}_{6} \mathrm{O}_{24} \mathrm{O}$ oxyapatite must await single crystal structure analyses. Kreidler and Hummel [8] reported the synthesis of strontium-phosphorus oxyapatite in vacuum at $1400^{\circ} \mathrm{C}$ but did not detect x-ray changes. Their

${ }^{4}$ This compound was found to be $(\mathrm{OH})^{-}$and $\left(\mathrm{CO}_{3}\right)^{=}$free by infrared absorption. Personal communication, Dr. Bruce Fowler, National Institutes of Health. 

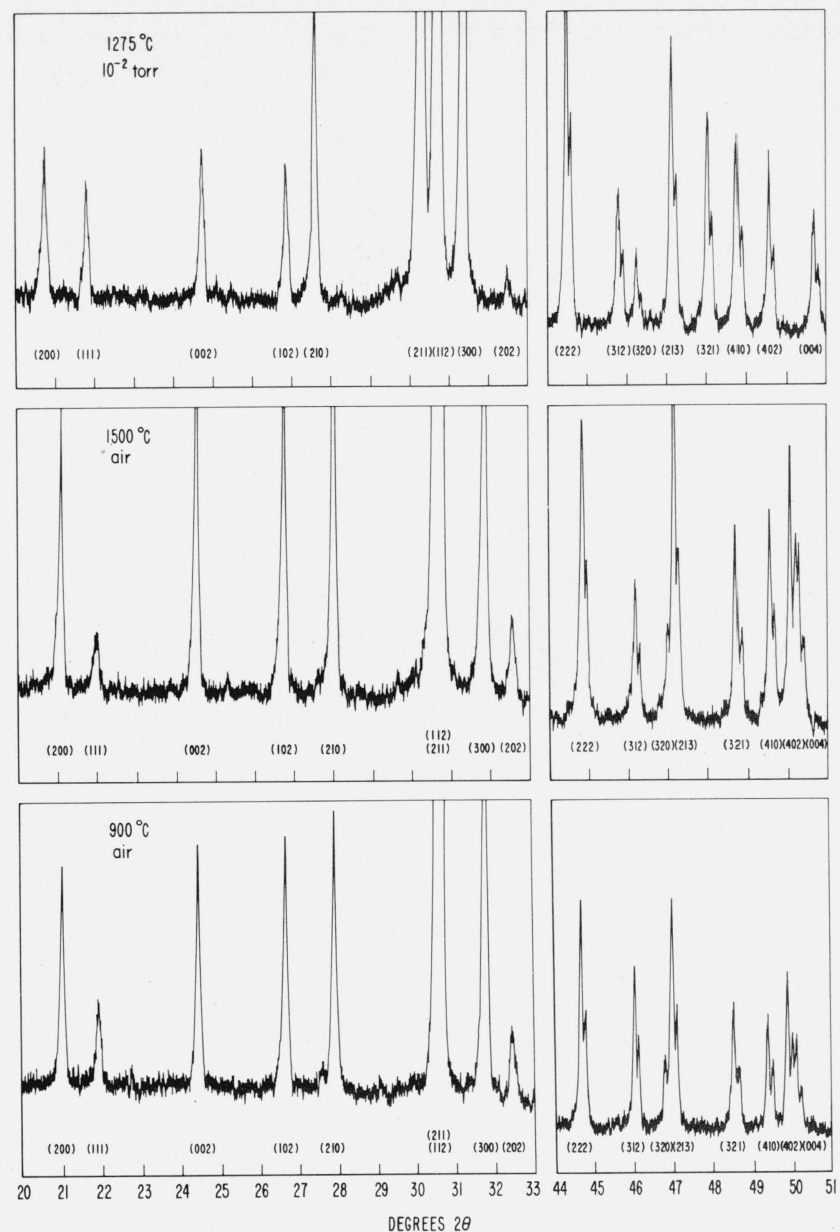

FIGURE 2. Comparison of portions of the powder patterns of $\mathrm{Sr}_{10} \mathrm{P}_{6} \mathrm{O}_{24}(\mathrm{OH})_{2}$, (bottom)-as prepared at $900{ }^{\circ} \mathrm{C}$ in air; (middle)-after heating at $1500^{\circ} \mathrm{C}$; (top)-heated at $1275^{\circ} \mathrm{C}$ and $10^{-2}$ torr.

inability to observe this phase may have been due to insufficient equilibration times and/or poor vacuum. In this study, approximately $1 \mathrm{~g}$ specimens heated between 1250 and $1500{ }^{\circ} \mathrm{C}$ from 15 to $113 \mathrm{hr}$ and less than $2 \times 10^{-2}$ torr (see table 1 ) yielded apatite phases with powder patterns similar in appearance to the air apatites. Analysis by NMR indicated that even these phases contain protons. Although their powder patterns are not exceedingly sharp, the cell parameters indicate an expansion of $a$ and contraction of $c$. Smaller specimens yield the new phase although a vacuum less than $10^{-2}$ torr and temperatures greater than $1100{ }^{\circ} \mathrm{C}$ are necessary.

In view of the results obtained on vacuum heated specimens another question can be raised concerning the nature of the products of high temperature in air experiments. Are the results shown in figure 1 a manifestation of stable or only metastable equilibrium? The answer to this question can only be decided after considerable experimentation with vacuum prepared starting material.

\section{2. $\mathrm{Ba}_{10} \mathrm{P}_{6} \mathrm{O}_{24}(\mathrm{OH})_{2}$ and $\mathrm{Pb}_{10} \mathrm{P}_{6} \mathrm{O}_{24}(\mathrm{OH})_{2}$}

A few attempts were made to correlate the high temperature "in-air" behavior of barium and leadphosphorus apatites with that of strontium. Experimental data are given in table 1.

Hydrothermal and low temperature $\left(700\right.$ to $900{ }^{\circ} \mathrm{C}$ ) specimens of barium-phosphorus apatite are identical, with $a=10.177 \AA$ and $c=7.731 \AA$. From just above 900 to $1500{ }^{\circ} \mathrm{C}$, as shown in figure 3 , cell parameters contract continuously with increasing temperature suggesting dehydroxylation as in the case of strontium. Some structural carbonate, however, may be present and the curve may represent, in reality, hydroxyl and carbonate loss. Phases can be easily reversed by reheating at lower temperatures. The $1600{ }^{\circ} \mathrm{C}$ apatite has $a=10.153 \AA$ and $c=7.696 \AA$. These values do not lie on the extrapolation of the $a$ and $c$ curves to $1600^{\circ} \mathrm{C}$. The fact that specimens at $1600{ }^{\circ} \mathrm{C}$ show partial melting and discoloration which may be due to reaction with platinum may explain this apparent anomaly. 


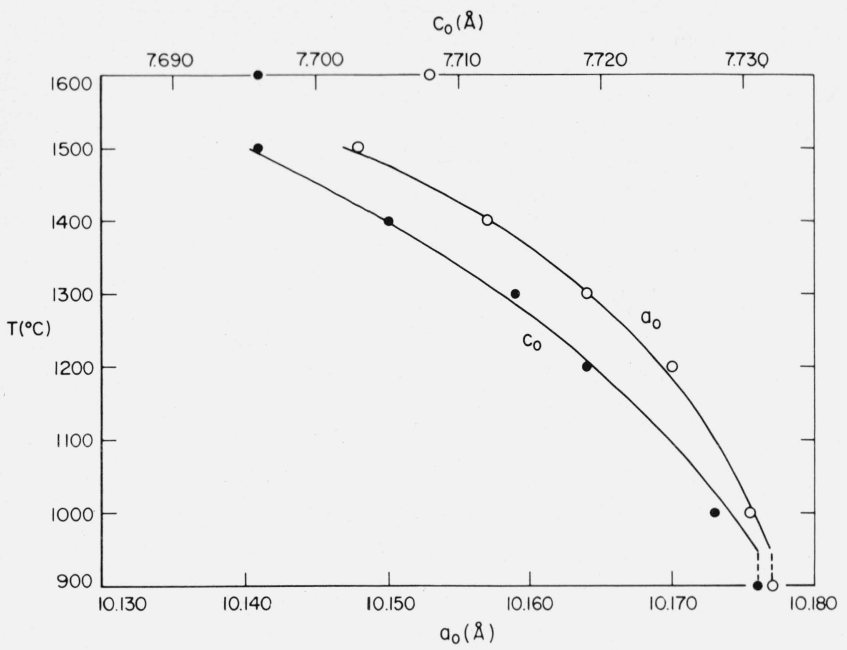

FIGURE 3. Unit-cell parameter changes of barium-phosphorus apatite as a function of the temperature of heating in air.

Alternatively, the slight increase in $a$ at $1600{ }^{\circ} \mathrm{C}$ may reflect the same tendency observed in the strontiumphosphorus apatite heated in vacuum. Regardless of the cause, a completely dehydroxylated barium oxyapatite does not appear to exist in air. For example, NMR analysis of a specimen held at $1500{ }^{\circ} \mathrm{C}$ for $20 \mathrm{hr}$ definitely established the presence of protons.

Hydrothermal and "in-air" lead-phosphorus apatites are not identical. The former has $a=9.878 \AA$ and $c=7.432 \AA$ while the latter has $a=9.825 \AA$ and $c=7.421 \AA$. Merker and Wondratscheck [7,9] reported a doubling of the $c$-axis for this compound. The powder patterns made in this study do not, and perhaps cannot, reveal this doubling. A specimen of the hydrothermal apatite heated in air at $700{ }^{\circ} \mathrm{C}$ for $65 \mathrm{hr}$ gave weight loss data suggesting the formula

$$
\mathrm{Pb}_{10} \mathrm{P}_{6} \mathrm{O}_{24}(\mathrm{OH})_{0.26} \mathrm{O}_{0.87} \mathrm{~V}_{0.87} \text {. }
$$

NMR analysis of this material reheated at $925{ }^{\circ} \mathrm{C}$ for $75 \mathrm{hr}$ also indicated that the phase was not totally deficient in protons. These data conflict with past reports $[6,8]$ regarding the synthesis of a completely dehydroxylated $\mathrm{Pb}_{10} \mathrm{P}_{6} \mathrm{O}_{24} \mathrm{O}$ type oxyapatite.
The "in-air" lead apatite does not show a progressive contraction of parameters with increase in temperature. In fact, crystals grown by slow cooling of the melt from 1000 to $950{ }^{\circ} \mathrm{C}$ yield powder patterns indistinguishable from lower temperature material. Significant, however, is the cell contraction of the hydrothermal apatite when partly dehydroxylated by heating in air.

\section{Summary}

Strontium and barium-phosphorus hydroxyapatites undergo cell parameter contractions at elevated temperatures in air. These can be correlated with progressive dehydroxylation according to

$$
\mathrm{M}_{10} \mathrm{P}_{6} \mathrm{O}_{24}(\mathrm{OH})_{2-2 \times} \mathrm{O}_{\times} \mathrm{V}_{\times} \text {. }
$$

Neither, however, form the limiting $\mathrm{M}_{10} \mathrm{P}_{6} \mathrm{O}_{24} \mathrm{O}$ type oxyapatite in air as complete dehydroxylation does not occur. The possibility exists that such a phase can be formed at elevated temperatures in vacuo. The unitcell dimensions of a new strontium-phosphate phase herein reported may represent those of the fully dehydroxylated apatite.

Dehydroxylation of lead-phosphorus hydroxyapatite in air does not produce a true oxyapatite but rather one which is still partially hydrated.

The writers wish to thank Thomas Farrar, National Bureau of Standards, for conducting the NMR analyses.

\section{References}

[1] Posner, A. S., Perloff, A., and Diorio, A. F., Acta Cryst. 11, 308-309 (1958).

[2] Negas, T., to be published.

[3] Ito, J., to be published.

[4] McConnell, D., Am. Mineralogist 23, 1-19 (1938).

[5] McConnell, D., Arch. Oral Biol. 10, 421-431 (1965).

[6] Balz, W., Dissertation, T. H. Karlsruhe, 1961.

[7] Merker, V. L., and Wondratschek, H., Z. Anorg. Allgen Chem. 306, 25-29 (1960).

[8] Kreidler, E. R., and Hummel, F. A., Inorg. Chem. 6, 884-891 (1967).

[9] Wondratschek, H., Neues Jahrb. Mineral. Abhand. 99, 113-160 (1963).

(Paper 72A6-528) 